\title{
THINK AND ANSWER!
}

Fábio Luís Alves Pena

Instituto Federal da Bahia - IFBA

Simões Filho - BA

Por que num dia frio, quando ficamos dentro de um automóvel com as janelas fechadas e o ar condicionado desligado, a superficie dos vidros embaça?

Você já deve ter visto que as paredes externas de um copo, que contém um líquido gelado, ficam cheias de gotículas de água! Isso acontece porque o vapor de água contido no ar do ambiente - estando a uma temperatura maior do que a do líquido e do copo - condensa ao atingir a superfície fria das paredes externas do copo, formando as gotículas de água (GRANDI, 1987). Tal fenômeno recebe o nome de condensação - processo pelo qual uma substância passa do estado de vapor ao estado líquido. Algo parecido também pode ser visto num dia frio quando ficamos dentro de um automóvel com as janelas fechadas e o ar condicionado desligado. Observa-se que a superfície dos vidros do automóvel embaça, isto é, que o vapor de água contido no interior do automóvel condensa ao entra em contato com o vidro frio.

Para que isso não atrapalhe a visibilidade do motorista, alguns automóveis são equipados com um acessório chamado desembaçador do vidro traseiro. Este acessório é constituído por filamentos (elementos eletro-térmicos) que ficam presos na superfície do vidro traseiro. Quando o vidro embaça, o motorista aciona um dispositivo, localizado no painel do automóvel, que faz uma corrente elétrica circular pelos filamentos. É o aquecimento produzido pela corrente elétrica (efeito Joule) que desembaça a superfície do vidro e impede que o vapor de água, contido no interior do automóvel, volte a condensar ao atingir tal superfície.

\footnotetext{
+ THINK AND ANSWER!

* Recebido: junho de 2010.

Aceito: novembro de 2010.
} 


\section{Referência Bibliográfica}

GRANDI, B. C. S. Já lhe perguntaram.... Caderno Catarinense de Ensino de Física, v. 4, n. 1, p. 49, abr. 1987. 